\title{
Membrane-Bound Fructose 1, 6-Bisphosphate Aldolase: Catalytic Activity and Mechanisms of Desorption
}

\author{
Kunio Nakashima, Machiko Ohtsuki and Syozo Tuboi \\ Department of Biochemistry, Yamagata University School \\ of Medicine, Yamagata 990-23
}

\begin{abstract}
Nakashima, K., Ohtsuki, M. and Tubor, S. Membrane-Round Fructose 1,6-Bisphosphate Aldolase: Catalytic Activity and Mechanisms of Desorption. Tohoku J. exp. Med., 1980, 130 (2), 143-152 — Fructose 1,6-bisphosphate aldolase [EC 4.1.2.13] in rat liver was found to be bound to the intracellular membraneous structures such as microsomes and nuclear membranes when the animals were fasted for $48 \mathrm{hr}$ or administered tryptophan. Upon refeeding the rats the aldolase was released into the cytosol. The membrane-bound aldolase was almost inactive, showing about 50-fold larger $K_{m}$ and a smaller $V_{\max }(37 \%)$ as compared with those of the free enzyme. The enzyme was released cooperatively from the membrane by exposure to fructose 1,6-bisphosphate, glyceraldehyde 3-phosphate or dihydroxyacetone phosphate at low concentrations. Apparent desorption constants $\left(K_{d}\right.$, concentrations necessary for $50 \%$ desorption of enzyme) for fructose 1,6-bisphosphate of the enzymes bound to microsomes, mitochondria and nuclei were estimated to be $8 \times 10^{-5}, 6.1 \times 10^{-6}$, and $4.8 \times 10^{-6} \mathrm{M}$, respectively, at $\mathrm{pH}$ 7.3. With the microsome-bound enzyme, $K_{d}$ values of $3.9 \times 10^{-4}, 4.1 \times 10^{-4}$, $2.7 \times 10^{-3}, \quad 1.1 \times 10^{-2}$ and $2.0 \times 10^{-2} \mathrm{M}$ were obtained for glyceraldehyde 3phosphate, dihydroxyacetone phosphate, fructose 1-phosphate, fumarate, and $\mathrm{KCl}$, respectively. Strong cooperativities were observed in the enzyme desorption by the substances which showed large $K_{d}$ values._- fructose 1,6-bisphosphate aldolase ; intracellular enzyme localization; desorption of membrane-bound enzyme; allosteric mechanism; active and inactive forms of enzyme
\end{abstract}

Recent investigations show that considerable fractions of certain enzymes which are classically considered to be located in the cytosol are bound to the membranous cellular components. Among these enzymes are hexokinase [EC 2.7. 1.1] (Crane and Sols 1953; Green et al. 1965; Hernandez and Crane 1966; Rose and Warms 1967; Katzen et al. 1970), triosephosphate isomerase [EC 5.3.1.1.] (Green et al. 1965), lactate dehydrogenase [EC 1.1.1.27] (Clarke and Masters 1973),

Received for publication, January 17, 1979.

This work was supported in part by Scientific Research Grants 158051, 167031 and 267037 from the Ministry of Education, Science and Culture, Japan, and a grant from the Foundation for the Promotion of Research on Medicinal Resources, Japan.

Requests for reprints should be addressed to Dr. S. Tuboi, Department of Biochemistry, Yamagata University School of Medicine, Yamagata 990-23, Japan.

Abbreviations used are: Hepes, 4-(2-hydroxyethyl)-1-piperazineethanesulfonic acid; FDP, fructose 1,6-bisphosphate. 
cytosolic fumarase [EC 4.2.1.2] (Nakashima et al. 1976, 1978), fructose 1,6bisphosphate aldolase (Roodyn 1956; Green et al. 1965; Arnold and Pette 1968, 1970; Clark et al. 1970; Clark and Masters 1973; Foemmel et al. 1975; Arion and Lange 1976) or cyclic AMP-dependent protein kinase [EC 2.7.1.70] (Kumon et al. 1970; Jard and Bastide 1970; Weller find Rodnight 1970; Gaballah and Popoff 1971; Maeno et al. 1971; Lemaire et al. 1971; Walton et al. 1971; Rubin et al. 1972). However, on fructose 1,6-bisphosphate aldolase it was also reported that binding of this enzyme to the particulate element represents an artifact of the dilution of the ionic concentration of the cytoplasmic milieu (Arion and Lange 1976). Therefore, the mechanisms and physiological significance of these binding phenomena are to be elucidated. The present paper is a report of the study on the conditions and mechanisms of the release of rat liver fructose 1,6-bisphosphate aldolase from intracellular membranous structures in vitro. The study also revealed that the membrane-bound aldolase had little catalytic activity.

\section{Experimental Procedures}

Rats. Male rats of the Wistar strain weighing 250-400 g were used throughout the experiments. Each rat was kept in the individual cage during the feeding experiments and was sacrificed at about $8: 30$ in the morning unless otherwise noted.

Diet. Laboratory chow containing soluble carbohydrate $(55.9 \%$ in weight), proteins $(21.3 \%)$, lipids $(6.1 \%)$, cellulose fibers $(4.3 \%)$, minerals $(6.4 \%)$ and vitamins was obtained from Funahashi Farm, Chiba, and was used as the normal diet.

Subcellular fractionation of rat liver. Rats were blown on the head and bled by cervical incision, then livers were perfused in situ with cold $0.25 \mathrm{M}$ sucrose. Livers were homogenized in $0.25 \mathrm{M}$ sucrose to obtain $33 \%$ homogenates and subcellular fractions were fractionated by the method described by Arion and Lange (1976). To assure the total cellular aldolase activity, a portion of liver was homogenized in $0.25 \mathrm{M}$ sucrose containing $0.15 \mathrm{M} \mathrm{KCl}$. For the subfractionation of the particles, the precipitates were suspended in 10 volumes $(\mathrm{v} / \mathrm{w})$ of $0.25 \mathrm{M}$ sucrose and centrifuged successively as originally reported by De Duve et al. (1955).

Assay of enzyme activity. Fructose 1,6-bisphosphate aldolase was assayed spectrophotometrically by the method of Racker $(1947)$ at $30^{\circ} \mathrm{C}$. The standard assay system $(2 \mathrm{ml})$ contained $50 \mathrm{mM}$ triethanolamine-HCl ( $\mathrm{pH} 7.5$ ), $2 \mathrm{mM}$ fructose 1,6-bisphosphate, 0.15 $\mathrm{mM} \mathrm{NADH}, 0.1 \mathrm{U}$ glycerol 3-phosphate dehydrogenase and $1.2 \mathrm{U}$ triose phosphate isomerase. In the assay of the enzyme bound to the particulate fractions, the rate of $\mathrm{NADH}$ oxidation in the absence of fructose 1,6-bisphosphate was also measured as the control.

Enzymes. Glycerol 3-phosphate dehydrogenase and triosephosphate isomerase were obtained from Boehringer Mannheim Corp., Mannheim, West Germany.

Reagents. Sodium salts of $\mathrm{NADP}^{+}$, ATP, ADP, GTP, TTP, ITP, CTP, UTP, acetyl CoA, phosphoenolpyruvic acid, glucose 1.P, fructose, puromycin hydrochloride, colchicine and Hepes were obtained from Sigma Chemical Co., St. Louis. Sodium salts of fructose-1,6$\mathrm{P}_{2}$, 2-P-glyceric acid, 3-P-glyceric acid, glucose-6-P , fructose-6-P, NAD ${ }^{+}$, dihydroxyacetone phosphate dimethylketal, glyceraldehyde-3-P diethylacetal and 2,3-diphosphoglycerate pentacyclohexylammonium were obtained from Boehringer Mannheim Corp., Mannheim. 


\section{Results}

Alterations of subcellular distribution of fructose 1,6-bisphosphate aldolase

In the livers of fed rats, about $78 \%$ of the total cellular fructose 1,6bisphosphate aldolase was free in the cytosol. When rats were fasted for $48 \mathrm{hr}$, the cytosolic aldolase was decreased with the concomitant increase in the particle-bound activity. This binding of the enzyme was enhanced by tryptophan administration, which blocked hepatic gluconeogenesis at the level of phosphoenolpyruvate carboxykinase (Ray et al. 1966; Foster et al. 1966; Veneziale et al. 1967) (Table 1). When the aldolase-bound particles were subfractionated, $31.0,17.8,4.7$ and $46.5 \%$ of the bound activity were associated with the nuclear, mitochondrial, lysosomal and microsomal fractions, respectively. Upon refeeding the fasted rats, the free aldolase was increased conversely (Table 1). Thus, under glycolytic condition the free form of fructose 1,6-bisphosphate aldolase was increased.

TABLE 1. Subcellular distribution of rat liver fructose 1,6.bisphosphate aldolase

\begin{tabular}{lcc}
\hline \multicolumn{1}{c}{ Conditions (number of rats) } & $\begin{array}{c}\text { Aldolase activity in } \\
\text { homogenates } \\
(\mu \text { moles/min/g liver } \pm \text { s.D. })\end{array}$ & $\begin{array}{c}\text { Relatvie activity in } \\
\text { supernatant } \\
\text { (\% } \% \text { s.o. })\end{array}$ \\
\hline Fed (4) & $16.0 \pm 0.9$ & $78.4 \pm 5.4$ \\
Fasted for $48 \mathrm{hr}(4)$ & $17.3 \pm 0.5$ & $68.5 \pm 0.9$ \\
Fasted for $48 \mathrm{hr}+$ tryptophan* (3) & $16.3 \pm 0.6$ & $47.8 \pm 4.9$ \\
Fasted for $48 \mathrm{hr}$, refed for 12 hr (3) & $16.6 \pm 1.2$ & $80.5 \pm 0.9$ \\
\hline
\end{tabular}

* Tryptophan (35 mg/100 g body weight) was intraperitoneally injected $3.5 \mathrm{hr}$ before killing.

\section{Desorption of aldolase from intracellular particles in vitro}

The metabolite specificity for the desorption of aldolase from the particulate fractions was studied in vitro. We confirmed the observation by Foemmel et al. (1975) that fructose 1,6-bisphosphate had a strong effect on release of the enzyme from the microsomal fraction. Moreover, glyceraldehyde 3-phosphate and dihydroxyacetone phosphate were also good substances for release of the enzyme (Table 2). Pyruvate, 2,3-diphosphoglycerate, nucleotide tri- and diphosphates showed a slight effect. Other metabolites in glycolysis and in the tricarboxylic acid cycle had negligible effects at $1 \mathrm{mM}$.

The desorption of the enzyme from the nuclear and mitochondrial fractions was also achieved by low concentrations of fructose 1,6-bisphosphate (Fig. 1). The desorption was dependent on $\mathrm{pH}$; this was particularly apparent with the microsomal and nuclear fractions. The desorption was favored in alkaline $\mathrm{pH}$ range with apparent $\mathrm{pK}$ values of around 7 (Fig. 2). With the mitochondrial fraction, less $\mathrm{pH}$ dependency was observed. Unless otherwise noted, $\mathrm{pH} 7.3$ was used for in vitro analysis.

The plots of released aldolase activity against fructose 1,6-bisphosphate 
TABLE 2. Specificity of metabolites for desorption of fructose 1,6-bisphosphate aldolase from rat liver microsomal fraction in vitro

\begin{tabular}{|c|c|c|c|}
\hline Metabolites added* & $\begin{array}{c}\text { Activity } \\
\text { released (\%) }\end{array}$ & Metabolites added* & $\begin{array}{l}\text { Activity } \\
\text { released (\%) }\end{array}$ \\
\hline None & 0 & Lactate & 1.2 \\
\hline Fructose-1, 6- $\mathrm{P}_{2}$ & 78.0 & Malate & 0 \\
\hline Glyceraldehyde-3-P & 71.6 & Citrate & 0 \\
\hline Dihydroxyacetone-P & 67.3 & ATP & 14.4 \\
\hline 2,3- $\mathrm{P}_{2}$-Glycerate & 12.4 & $\mathrm{ADP}$ & 11.9 \\
\hline 3-P-Glycerate & 0 & GTP & 19.6 \\
\hline 2-P-Glycerate & 0 & TTP & 13.3 \\
\hline P-Enolpyruvate & 0 & ITP & 10.8 \\
\hline Acetyl ${ }^{2} \mathrm{CoA}$ & 0 & CTP & 18.2 \\
\hline Fructose-1-P & 4.0 & UTP & 14.5 \\
\hline Fructose-6-P & 0 & Dibutyryl cAMP† & 0 \\
\hline Glucose-1-P & 1.8 & EDTA & 0 \\
\hline Glucose-6-P & 5.4 & Puromycin & 0 \\
\hline Pyruvate & 11.8 & $\mathrm{KCl}$ & 0 \\
\hline
\end{tabular}

* To $0.2 \mathrm{ml}$ of aldolase-rich microsomal fraction ( $\mathrm{pH}$ adjusted to 7.3), was added $1.8 \mathrm{ml}$ of $0.25 \mathrm{M}$ sucrose- $10 \mathrm{mM}$ Hepes containing $1.1 \mathrm{mM}$ metabolite $\left(\mathrm{pH} \mathrm{7.3)}\right.$ and the mixture was incubated at $30^{\circ} \mathrm{C}$ for $30 \mathrm{sec}$. The mixture was then centrifuged at $105,000 \times \mathrm{g}$ for $60 \mathrm{~min}$ at $4^{\circ} \mathrm{C}$, and the supernatant solution was analyzed for released activity and expressed as percent of the original activity, assaying in the standard assay system.

$\dagger$ Added at $0.01 \mathrm{mM}$.

concentration did not give hyperbolic curves (Fig. 1A), suggesting that more than one fructose 1,6-bisphosphate molecule per enzyme molecule participated cooperatively in formation of free enzyme-fructose 1,6-bisphosphate complex.

If one assumes the following over-all reaction,

$$
\mathrm{E}-+n \mathrm{~A}=\mathbf{E}-\mathbf{A}_{n}
$$

then

$$
K=\frac{\left[\mathrm{E}-\mathrm{A}_{n}\right]}{[\mathrm{E}-][\mathrm{A}]^{n}}
$$

and

$$
\log \frac{\left[\mathrm{E}-\mathrm{A}_{n}\right]}{[\mathrm{E}-]}=\log K+n \log [\mathrm{A}]
$$

where $\mathrm{E}-=$ membrane-bound enzyme, $\mathrm{E}-\mathrm{A}_{n}=$ released enzyme-effector complex, $A=$ effector which released enzyme from membrane, $n=$ number of effector bound to one molecule of enzyme, $K=$ apparent over-all equilibrium constant.

In Fig. $1 B$, writing $r /(R-r)$ and [FDP] for [E-A $n] /[\mathrm{E}-]$ and $[\mathrm{A}]$, respectively (where $r=$ released enzyme activity and $R=100 \%$ released activity which was obtained by assaying with particulate fractions in the standard assay system), the logarithm of $r /(R-r)$ was plotted against log [FDP] employing the data given in Fig. $1 A$. The slope of each curve corresponds to $n$, and the vertical intercept where log $[\mathrm{FDP}]=0$ gives $\log K$. The logarithm of apparent desorption constant $\left(K_{d}\right.$, concentration necessary for $50 \%$ desorption) for FDP can be obtained as the horizontal intercept where $\log r /(R-r)=0$. The curves were apparently biphasic, and at higher 

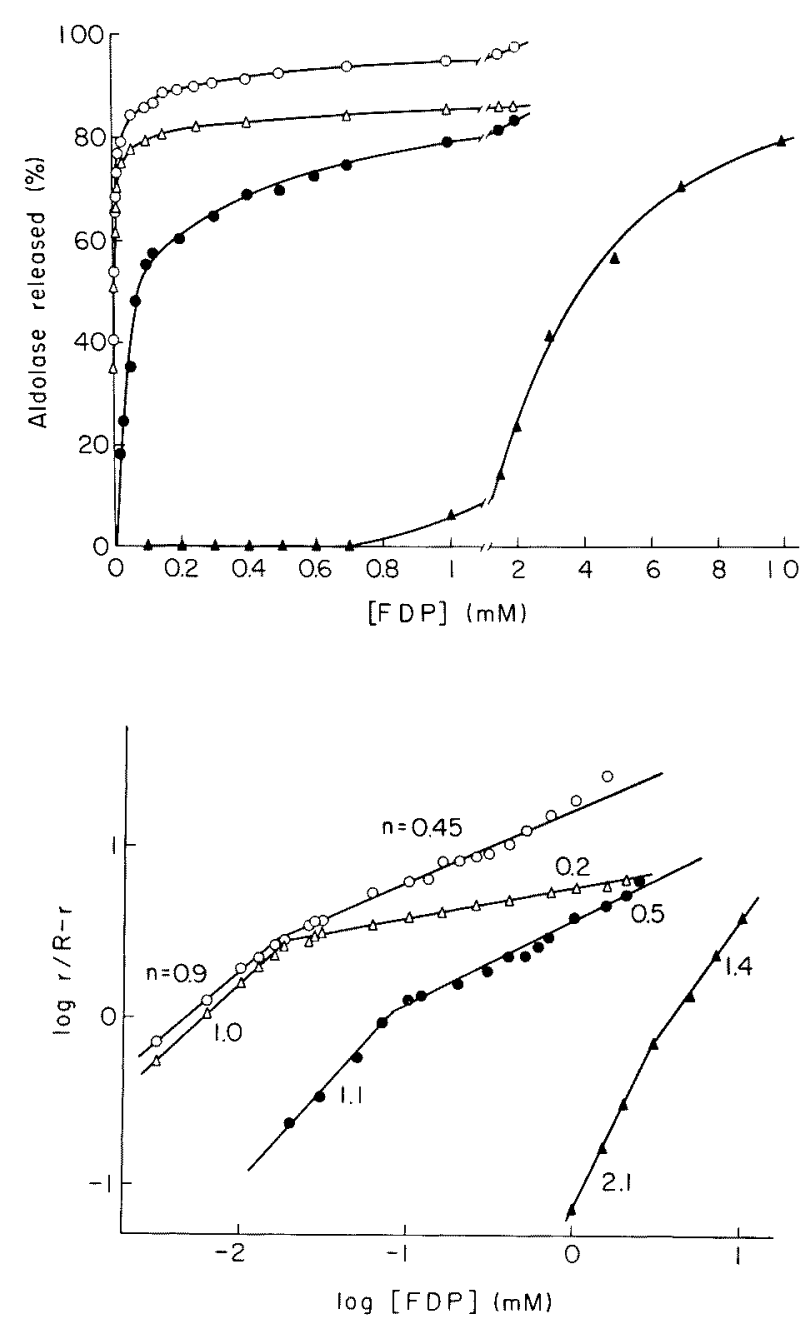

Fig. 1. Effect of concentration of fructose 1,6-bisphosphate on in vitro desorption of aldolase from the nuclear $(\mathrm{O}-\mathrm{O})$, mitochondrial $(\Delta-\Delta)$ and microsomal $(--)$ fractions. $A$ (upper): Each particulate fraction was incubated at $\mathrm{pH} 7.3$ with fructose 1,6-bisphosphate at varied concentrations, and the released enzyme activity was determined as described in Table 2 except that centrifugations for mitochondria and nuclei were performed at $10.000 \times \mathrm{g}$ for $10 \mathrm{~min}$. The data at $\mathrm{pH} 5.7$ with the

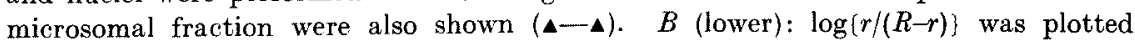
against $\log [$ FDP] employing the data in $A$, as described in the text.

concentrations of fructose 1,6-bisphosphate the $n$-values were reduced, suggesting the presence of a negative cooperativity for binding of the ligand. This nature of the desorption reaction was essentially common to the three particulate fractions. At the lower $\mathrm{pH}$, the larger $K_{d}$ and $n$ were obtained.

Dihydroxyacetone phosphate also exhibited a biphasic desorption pattern of 


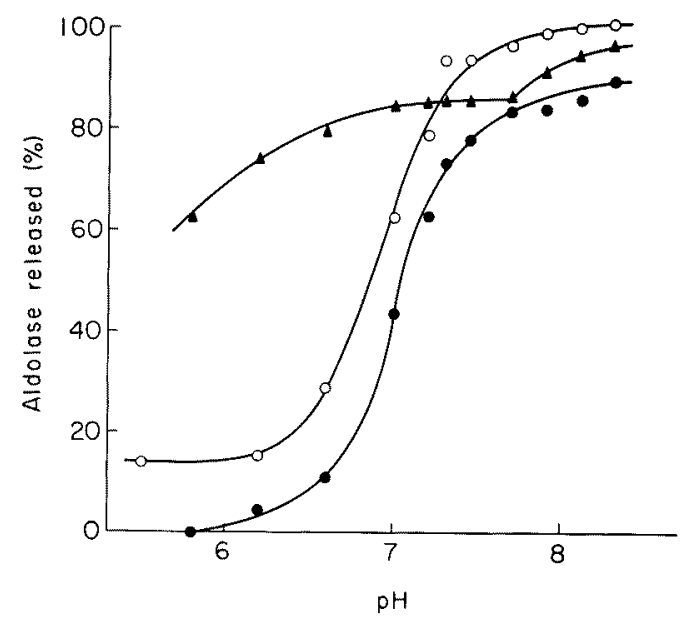

Fig. 2. Effect of $\mathrm{pH}$ on desorption of aldolase from the nuclear $(0-0)$, mitochondrial ( $-\mathbf{\Delta})$ and microsomal fractions (-). Each subcellular fraction was incubated with $0.5 \mathrm{mM}$ fructose 1,6-bisphosphate in $0.25 \mathrm{M}$ sucrose- $10 \mathrm{mM}$ Hepes at desired $\mathrm{pH}$, and the release of the enzyme was analzyed as described in Fig. 1.

Fig. 3. Desorption of aldolase from the microsomal fraction by dihydroxyacetone phosphate $(0-0)$, fructose 1-phosphate $(\Delta-\Delta)$ and $\mathrm{KCl}$ (-)). The microsomal fraction was incubated at $\mathrm{pH} 7.3$ with ligands indicated, and the released enzyme activity was analyzed as described in Table 2. The longarithm of $r /(R-r)$ was plotted against the logarithm of the concentration of ligands as described in the text.

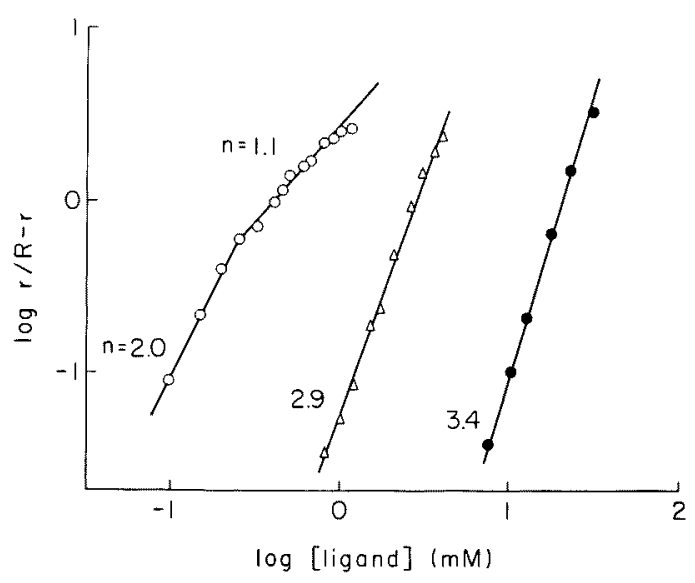

TABLE 3. Apparent desorption constants for various substances in rat liver fructose 1,6-bisphosphate aldolase desorption from the particulate fractions at $p H 7.3$

\begin{tabular}{lccc}
\hline \multicolumn{1}{c}{ Substances } & \multicolumn{3}{c}{$K_{d}$ in the system of } \\
\cline { 2 - 4 } & Microsomes & Nuclei & Mitochondria \\
\hline Fructose-1,6-P & $8.0 \times 10^{-5}$ & $4.8 \times 10^{-6}$ & $6.1 \times 10^{-6}$ \\
Dihydroxyacetone-P & $4.1 \times 10^{-4}$ & $1.8 \times 10^{-4}$ & $9.2 \times 10^{-5}$ \\
Glyceraldehyde-3-P & $3.9 \times 10^{-4}$ & $2.9 \times 10^{-4}$ & $2.6 \times 10^{-4}$ \\
Fructose-1-P & $2.7 \times 10^{-3}$ & $2.6 \times 10^{-3}$ & - \\
Fumarate & $1.1 \times 10^{-2}$ & - & - \\
KCl & $2.0 \times 10^{-2}$ & - & - \\
\hline
\end{tabular}

aldolase (Fig. 3). An almost identical curve was obtained with glyceraldehyde 3phosphate (data not shown). Other substances including fructose 1-phosphate, which is another substrate for liver fructose 1,6-bisphosphate aldolase (Penhoet et 
al. 1966; Gracy et al. 1970), showed larger $K_{d}$ and $n$ values in curves of single phase. The largest $K_{d}$ and $n$ were obtained with $\mathrm{KCl}$. Apparent desorption constants for various substances in the binding phenomenon of fructose 1,6-bisphosphate aldolase were summarized in Table 3.

Catalytic activity of membrane-bound fructose 1,6-bisphosphate aldolase

It is very important to know whether the membrane-bound enzyme is enzymatically active or not. To examine this question, it is necessary to use an assay system in which no desorption of the enzyme occurs. In $0.25 \mathrm{M}$ sucrose$10 \mathrm{mM}$ Hepes ( $\mathrm{pH} 5.7$ ), the enzyme was not released from the microsomal fraction by the substrate fructose 1,6-bisphosphate at the concentrations up to $0.7 \mathrm{mM}$ (Fig. 1A). Assaying activities in this medium, hyperbolic saturation curves for fructose 1,6-bisphosphate were obtained for both cytosolic free and microsome-bound enzymes. However, the $K_{m}$ of the bound enzyme was approximately 50 times larger than that of the free enzyme. Moreover, the maximum velocity was only $37 \%$ of the free enzyme (Fig. 4). $V_{\max }$ of the free enzyme at this $\mathrm{pH}$ was about $80 \%$ of that obtained in the standard assay system.

Fig. 4. Initial velocity pattern for fructose 1,6-bisphosphate cleavage by the soluble and microsomebound aldolases. Assays were performed at $\mathrm{pH} 5.7$ in $0.25 \mathrm{M}$ sucrose-10 mM Hepes. $0-0$, bound enzyme; - $\bullet$, free enzyme. Double reciprocal plots were shown in the inset. $\Delta-\Delta, K_{m}=1.0 \times$ $10^{-\mathrm{3}} \mathrm{M} ; \Delta-\Delta \quad K_{m}=2.1 \times 10^{-5} \mathrm{M}$. The $K_{m}$ and $V_{\max }(100 \%$ activity) were estimated using the least squares method (Wilkinson 1961).

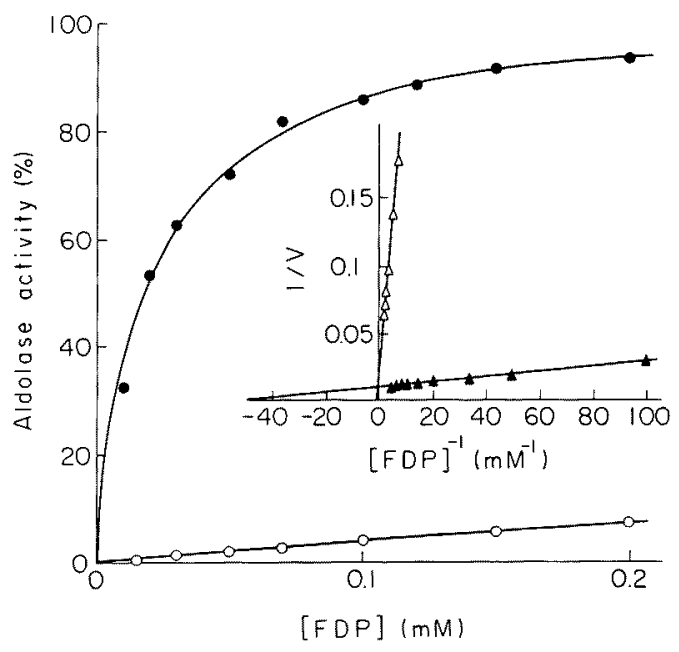

\section{Discussion}

Two major mechanisms in regulation of intracellular enzyme activity are generally accepted. One is the synthesis and degradation of enzyme protein, and the other is the control of its activity by the specific effectors or by enzyme interconversions. Fructose 1,6-bisphosphate aldolase turns over slowly in the cell, and the apparent half-life of 4.9 days had been reported for liver enzyme (Kuehl and Sumsion 1970). This rate of turnover may be too slow for enzyme regulation by induction and degradation. And very few in vitro control mechanisms 
of enzyme activity have been reported for this enzyme (Horecker et al. 1972), leading to a concept that fructose 1,6-bisphosphate aldolase is a constitutive enzyme. We now suggest another possible control mechanism of rat liver aldolase activity in the cell, that is, the enzyme becomes inactive by binding to cellular membraneous components when the concentrations of the substrates are low. Foemmel et al. (1975) have observed that rat liver aldolase is readily bound to the microsomal fraction after dialysis. The binding is favored in acid $\mathrm{pH}$ range, and the $\mathrm{pH}$ curve forms a mirror image with curve for the desorption shown in Fig. 2. The present study also suggests that the intracellular localization of rat liver aldolase is altered under certain conditions being controlled by the concentrations of metabolic intermediates. The smallest desorption constant obtained with fructose 1,6-bisphosphate indicates that it may play the principal role in those mechanisms.

Arion and Lange (1976) reported that, in the livers of rats fasted overnight, about $95 \%$ of the cellular aldolase was free in the cytosol. There is a deep discrepancy between their concept on the localization of aldolase in liver cell and our's or other's (Foemmel et al. 1975). However, Airon and Lange anesthetized the rats with diethyl ether, which is well known as a drastic hyperglycemic agent through the action on the liver (Levine 1966). Metabolic intermediates such as fructose 1,6-bisphosphate would be increased in the livers of these animals. They also added dextran to the homogenates before centrifugation. We found that this reagent is highly effective in releasing the enzyme from the membrane. Even though its concentration used was very low, the distribution of aldolase might have been affected in their experiments. Another discrepancy was found with aldolase activity in the cell. The units obtained by them were only about one fifth of those in our study. These discrepancies remain to be resolved.

The desorption of fructose 1,6-bisphosphate aldolase from the membrane is not strictly specific to its substrates; any other substance tested releases the enzyme but at much higher concentrations. In addition, the membrane-bound enzyme also showed a little catalytic activity, suggesting that the enzyme may bind to the membrane at a site somewhat different from its catalytic sites.

Clarke and Masters (1973) observed that a large part of the brain aldolase is associated with nuclei, mitochondria and microsomes, showing a differential distribution between A- and C-type isoenzymes. Arnold and Pette (1968, 1970) reported that the muscle aldolase can be bound to structure proteins of the muscle such as F-actin in vitro, and that the binding is prevented by the presence of fructose 1,6-bisphosphate, ATP or ADP. There is the possibility that the localization of the brain and muscle aldolases is also under similar regulations.

\section{References}

1) Arion, W.J. \& Lange, A.J. (1976) The intracellular location of hepatic fructose 1,6bisphosphate aldolase. Biochem. biophys. Res. Commun., 68, 770-775.

2) Arnold, H. \& Pette D. (1968) Binding of glycolytic enzymes to structure porteins of the muscle. Eur. J. Biochem., 6, 163-171. 
3) Arnold, H. \& Pette D. (1970) Binding of aldolase and triosephosphate dehydrogenase to F-actin and modification of catalytic properties of aldolase. Eur.J. Riochem., 15, 360-366.

4) Clarke, F.M. \& Masters, C.J. (1973) On the distribution of aldolase isoenzymes in subcellular fractions from rat brain. Arch. Biochem. Biophys., 156, 673-683.

5) Clarke, F.M., Masters, C.J. \& Winzor, D.J. (1970) The differential adsorption of aldolase isozymes in rat brain. Biochem. $J ., 118,325-327$.

6) Crane, R.K. \& Sols, A. (1953) The association of hexokinase with particulate fractions of brain and other tissue homogenates. J. biol. Chem., 203, 273-292.

7) De Duve, C., Pressman, B.C., Gianetto, R., Wattiaux, R \& Appelmans, F. (1955) Tissue fractionation studies 6 . Intracellular distribution patterns of enzymes in rat-liver tissue. Biochem. J., 60, 604-617.

8) Foemmel, R.S., Gray, R.H. \& Bernstein, I.A. (1975) Intracellular localization of fructose 1,6-bisphosphate aldolase. J. biol. Chem., 250, 1892-1897.

9) Foster, D.O., Ray, P.D. \& Lardy, H.A. (1966) A paradoxical in vivo effect of $\mathrm{L}_{\text {- }}$ tryptophan on the phosphoenolpyruvate carboxykinase of rat liver. Biochemistry, 5, $563-569$.

10) Gaballah, S. \& Popoff, C. (1971) Localization of adenosine $3^{\prime}, 5^{\prime}$-monophosphatedependent protein kinase in brain. J. Neurochem., 18, 1795-1797.

11) Gracy, R.W., Lacko, A.G., Brox, L.W., Adelman, R.C. \& Horecker, B.L. (1970) Structural relations in aldolases purified from rat liver and muscle and Novikoff hepatoma. Arch. Biochem. Biophys., 136, 480-490.

12) Green, D.E., MurJr, E., Hultin, H.O., Richardson, S.H., Slamon, B., Brierley, G.P. \& Baum, H. (1965) Association of integrated metabolic pathways with membranes. 1. Glycolytic enzymes of the red blood corpuscle and yeast. Arch. Biochem. Biophys, $112,635-647$.

13) Hernandez, A. \& Crane, R.K. (1966) Association of heart hexokinase with subcellular structure. Arch. Biochem. Biophys., 113, 223-229.

14) Horecker, B.L., Tsolas, O. \& Lai, C.Y. (1972) Aldolases. In: The Enzymes, edited by P.D. Boyer, Vol. 7, Academic Press, New York-London, pp. 213-258.

15) Jard, S. \& Bastide, F. (1970) A cyclic AMP-dependent protein kinase from bladder epithelial cells. Biochem. biophys. Res. Commun., 39, 559-566.

16) Katzen, H.M., Soderman, D.D. \& Wiley C.E. (1970) Multiple forms of hexokinase. Activities associated with subcellular particulate and soluble fractions of normal and streptozotocin diabetic rat tissues. $J$. biol. Chem., 245, $4081-4096$.

17) Kuehl. L. \& Sumsion, E.N. (1970) Turnover of several glycolytic enzymes in rat liver. J. biol. Chem., 245, 6616-6623.

18) Kumon, A., Yamamura, H. \& Nishizuka, Y. (1970) Mode of action of adenosine $3^{\prime}, 5^{\prime}$ cyclic phosphate on protein kinase from rat liver. Biochem. biophys. Res. Comun., 41, 1290-1297.

19) Lemaire, S., Pelletier, G. \& Labrie, F. (1971) Adenosine 3',5'-monophosphatedependent protein kinase from bovine anterior pituitary gland. II. Subcellular distribution. J. biol. Chem., 246, 7303-7310.

20) Levine, R. (1966) Carbohydrate metabolism. In: Diseases of Metabolism, edited by G.G. Duncan W.B. Saunders Company, Philadelphia-London, pp. 105-190.

21) Maeno, H. \& Johnson, E.M. \& Greengard, P. (1971) Subcellular distribution of adenosine $3^{\prime}, 5^{\prime}$-monophosphate-dependent protein kinase in rat brain. $J$. biol. Chem., 246, 134-142.

22) Nakashima, K., Takeda, M. \& Tuboi, S. (1976) Dietary control of intracellular distribution of rat liver fumarase. Biochem. biophys. Res. Commun., 72, 1562-1569.

23) Nakashima, K., Ohtsuki, M. \& Tuboi, S. (1978) Mechanisms of desorption and adsorption of liver cytosolic fumarase to cellular membranous components. $J$. Biochem., 84, 361-367.

24) Penhoet, E., Rajkimuar, T. \& Rutter, W.J. (1966) Multiple forms of fructose diphosphate aldolase in mammalian tissues. Proc. nat. Acad. Sci. USA, 65, 1275-1282. 
25) Racker, E. (1947) Spectrophotometric measurement of hexokinase and phosphohexokinase activity. J. biol. Chem., 167, 843-854.

26) Ray, P.D., Foster, D.O. \& Lardy, H.A. (1966) Paths of carbon in gluconeogenesis and lipogenesis. IV. Inhibition by L-tryptophan of hepatic gluconeogenesis at the level of phosphoenolpyruvate formation. J. biol. Chem., 241, 3904-3908.

27) Roodyn, D.B. (1956) The enzymic properties of rat-liver nuclei. 2. Factors affecting the aldolase activity of rat liver nuolei. Biochem. J., 64, 368-373.

28) Rose, I.E. \& Warms, J.V.B. (1967) Mitochondrial hexokinase. Release, rebinding, and location. J. biol. Chem., 242, 1635-1645.

29) Rubin, C.S., Erlichman, J. \& Roson, O.M. (1972) Cyclic adenosine 3',5'-monophosphate-dependent protein kinase of human erythrocyte membranes. $J$. biol. Chem., 247, 6135-6139.

30) Veneziale, C.M., Walter, P., Kneer, N. \& Lardy, H.A. (1967) Influence of L-tryptophan and its metabolites on gluconeogenesis in the isolated, perfused liver. Biochemistry, 6, 2129-2138.

31) Walton, G.M., Gill, B.N., Abrass, I.B. \& Garren, L.D. (1971) Phosphorylation of ribosome-associated protein by an adenosine $3^{\prime}, 5^{\prime}$-cyclic monophosphate-dependent protein kinase. Location of the microsomal receptor and protein kinase. Proc. nat. Acad. Sci. USA, 68, 880-884.

32) Weller, M. \& Rodnight, R. (1970) Stimulation by cyclic AMP of intrinsic protein kinase activity in ox brain membrane preparations. Nature, 225, 187-188.

33) Wilkinson, G.N. (1961) Statistical estimations in enzyme kinetics. Biochem. J., $80,324-332$. 